\title{
sciendo
}

CIVIL AND ENVIRONMENTAL ENGINEERING REPORTS

E-ISSN 2450-8594

CEER 2018; 28 (2): 111-123

DOI: $10.2478 /$ ceer-2018-0023

Original Research Article

\section{THE HISTORIC STEEL BRIDGE IN STANY. HERITAGE PRESERVATION. CHANGING THE FUNCTION}

\author{
Bartosz MICHALAK ${ }^{1}$, Wojciech ECKERT ${ }^{1}$ \\ University of Zielona Góra, Zielona Góra, Poland.
}

\begin{abstract}
Stany is a small village located near the town of Nowa Sól in the Lubusz Voivodship. Within a few hundred meters of the buildings there is one of the most interesting monuments in the Lubusz Voivodship - a railway bridge dating back to the beginning of the 20th century. It was designed by the company BEUCHELT \& Co. The bridge consists of fourteen spans with a total length of $642 \mathrm{~m}$. It was in continuous operation until 1994. Since then the object has not been used and its technical condition is deteriorating year by year. The bridge is unique in Poland and in Europe, which means that it could be interesting to carefully describe it and investigate its structure. There are plans to repair its structure in the following year. The bridge will not be used in its previous function, but it will be renovated and adapted for cyclists.
\end{abstract}

Keywords: Beuchelt, steel bridge, Stany, steel lattice, Odra river

\section{INTRODUCTION}

The company ZASTAL, existing at present in Zielona Góra, was established in 1945 and has been a leading manufacturer of steel structures and rolling stock for many years. However, the plant was not built from scratch. Shortly after the Second World War, the Polish administration set up a company based on the

\footnotetext{
${ }^{1}$ Corresponding author: University of Zielona Gora, Faculty of Civil Engineering, Architecture and Environmental Engineering, Institute of Building Engineering, Z. Szafrana st 1, 65-516 Zielona Góra, Poland, e-mail: b.michalak@ib.uz.zgora.pl, tel. +48683287343, e-mail: w.eckert@ib.uz.zgora.pl, tel. 683282651
} 
structure left by the Germans - the company founded by Georg Beuchelt [8]. In 1871 the management of the Niederschlesischen Maschinenbau AG (the Lower Silesian Machinery Construction Company Joint Stock Company) from Zgorzelec, the main contractor of the Berlin-Wrocław railway line, decided to open a branch of their company in Grünberg in Schlesien, today Zielona Góra. In 1874 the engineer Georg Beuchelt started work in the already existing factory. Apart from managing the factory, Beuchelt was also involved in politics, and as a conservative he was a member of the Prussian Landtag and a deputy to the Reichstag from the Zielona Góra-Legnica-Kożuchów district. In the town he was a councillor and the chairman of the city council [3]. At that time the branch of the factory in Zgorzelec, where Beuchelt worked, manufactured agricultural machinery. Despite the favourable geographic position that could provide a large number of customers, the crisis in agriculture forced the plant's management to declare bankruptcy in mid-1876. On 1 December 1876 Beuchelt bought the company and restructured it. Beuchelt invested in the development of railways and founded the Fabrik für Brückenbau und Eisenkonstruktionen Beuchelt \& Co. Grünberg in Schlesien (the Bridge and Steel Building Factory Beuchelt \& Co. Zielona Góra in Silesia). At first the company manufactured components of bridges and steel viaducts, in 1886 it started manufacturing different types of railway carriages, including the first luxury railway carriages in the German Empire as well as the first special carriages such as refrigerators and cisterns [5]. Over the course of more than 60 years (1876-1945) Beuchelt \& Co. built almost 500 bridges in Europe, Africa and Asia, including 42 on the Oder River and 52 on its tributaries. Apart from bridge construction, the company also designed and built steel structures for buildings, industrial halls, railway stations and roof structures, freight and passenger carriages, which amounted to a total of 25,000, also artillery components and Mercedes-Benz mail buses, which is remarkable, and during World War 2 hulls for U-boats. Among the most famous structures built by the company are those located in Wrocław: Grunwaldzki Bridge, formerly Imperial Bridge (Kaiserbrücke), Zwierzyniecki Bridge and the roof structure of the main railway station and of the ZOO. Moreover, the company also built the draw bridge in Szczecin, the unique in its design rotating bridge in Gżycko, Empress Louise Bridge in Tylża (now the Kaliningrad District in Russia), the steel bridge in Bytom Odrzański (now non-existent), the steel road bridge in Krosno Odrzańskie, the hall of Berlin-ZOO Station and a few other bridges in Berlin, the main railway station and the bridge across the Oder River in Frankfurt an der Oder. In Zielona Góra the company built the roof structure of the railway station, the structure of the modernist building of the sports hall, the structure of the roof truss of the Most Holy Saviour church and the roof girders of the theatre. In Poznan the company built St. Roch Bridge and the roof structure of the main railway station. The company also built the Palm House and the roof structure of the main railway station in Bucharest, the market hall in Focşani in Romania and the facilities of the Port of Haidar Pasha in the Asian part 
of Istanbul. Moreover, in 1903 Beuchelt \& Co. won a tender for the construction of engineering facilities on the Damascus-Bagdad railway line. The company completed the whole project from the design stage, through the production of components, to their assembly on site [4]. The company also participated in the construction of the Trans-Siberian railway in Russia [5, 6].

\section{BRIDGE IN STANY}

An important project undertaken by the factory was the construction of the bridge over the Oder River in Stany. Stany (German: Aufhalt) is a small village belonging to the administrative commune of Nowa Sól in the Lubusz Voivodship.

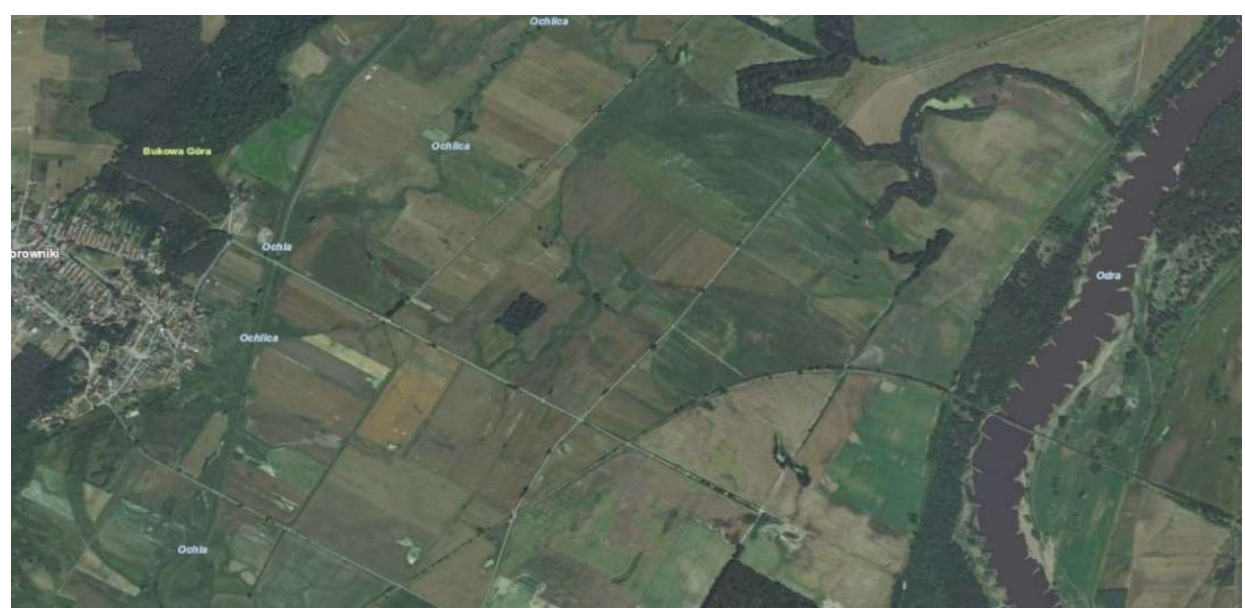

Fig. 1. Location of the object (Geoportal, 2018)

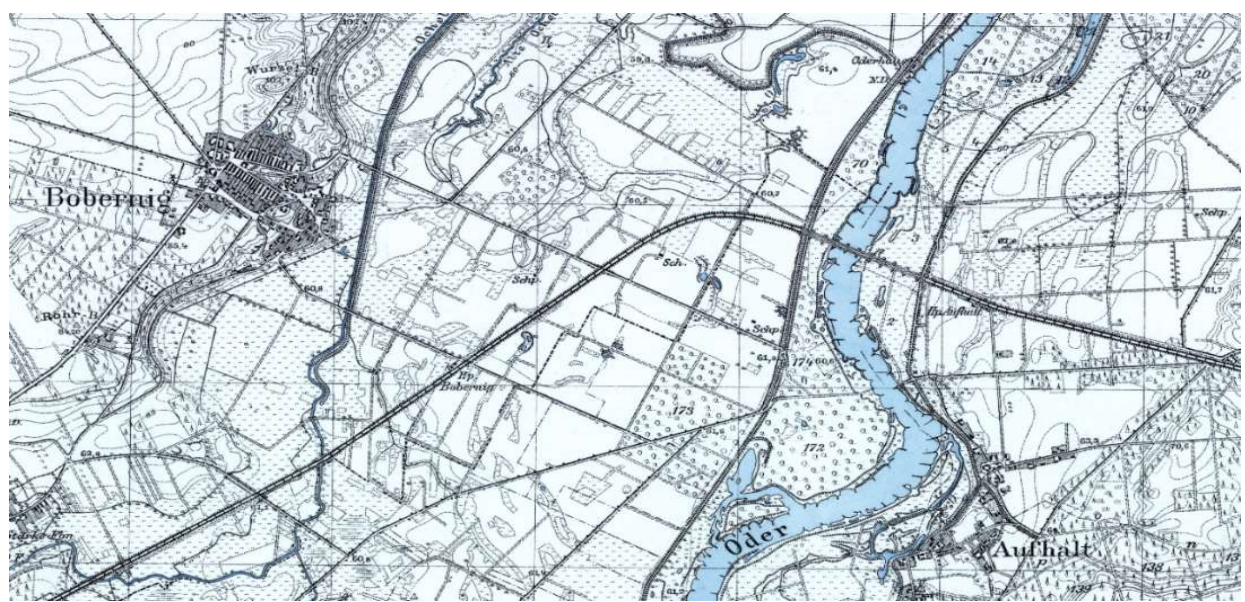

Fig. 2. Location of the object (Messtichblatt, 1922) 
Within a few hundred meters of its buildings there is one of the most interesting monuments in the Lubusz Voivodship - a railway bridge dating back to the beginning of the 20th century.

Design work on a new crossing over the Oder River started in October 1903 during the construction of the Wolsztyn - Nowa Sól railway line, and in 1905 the object was put into operation. The investor, Königliche Eisenbahn Direktion Posen (the Management of the Royal Railways in Poznań), entrusted the project and construction work to Beuchelt \& Co. The bridge consists of fourteen spans with a total length of $642 \mathrm{~m}$.

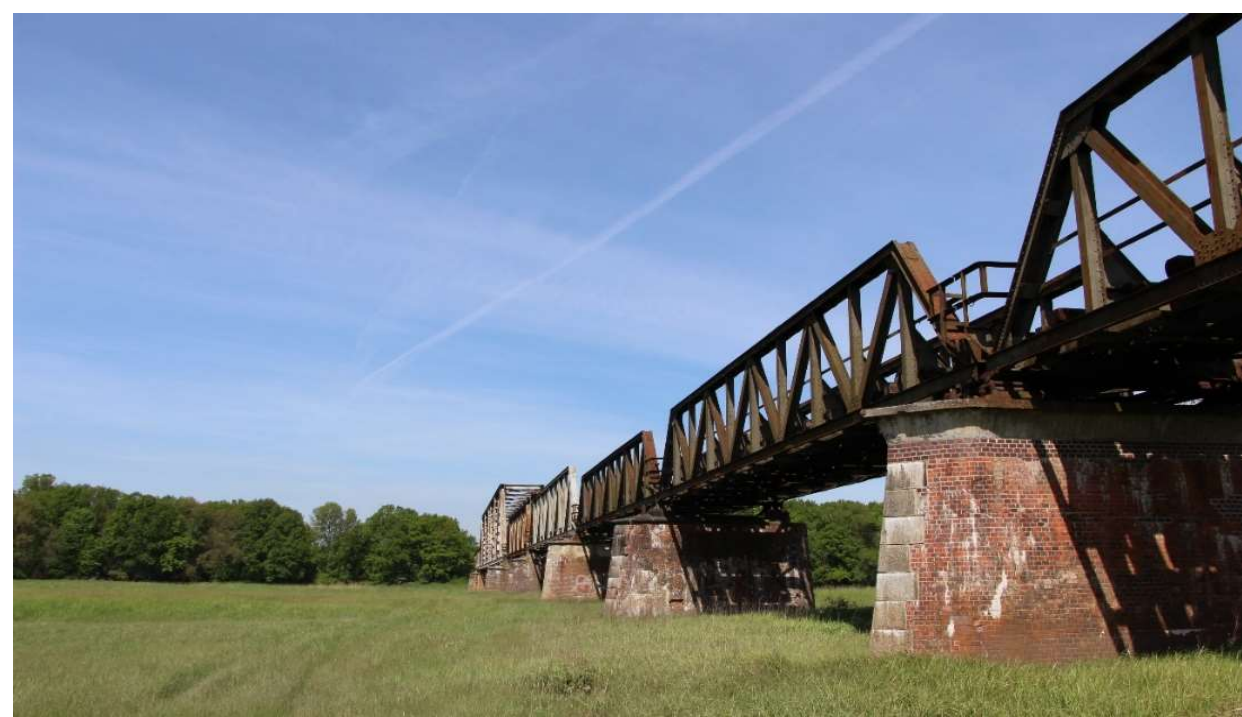

Fig. 3. View of the bridge from the eastern side (photo by the Author, 2017)

The longest river span is 100.01 meters long. As erroneously put in many sources, it is neither the longest steel lattice railway bridge in Poland nor the bridge with the longest river span. The longest lattice railway bridge in Poland is Bronisław Malinowski Bridge in Grudziądz, which is $1098 \mathrm{~m}$ long, while the longest river span with a length of $100.62 \mathrm{~m}$ is located in the structure of the ford bridge in Bydgoszcz. Therefore, it is possible to say that the length of the river span gives the bridge in Stany a place among the top bridges in Poland and the first place in the Lubusz Voivodship.

\section{DESIGN AND CONSTRUCTION}

In the original design documentation there are drawings of as many as seven concepts of the bridge to be considered at the design stage. For example, one of the options was a variant with three river spans of $100.00 \mathrm{~m}$ each, a static layout 
of the river section as a continuous beam, or a combination of a steel structure with masonry.

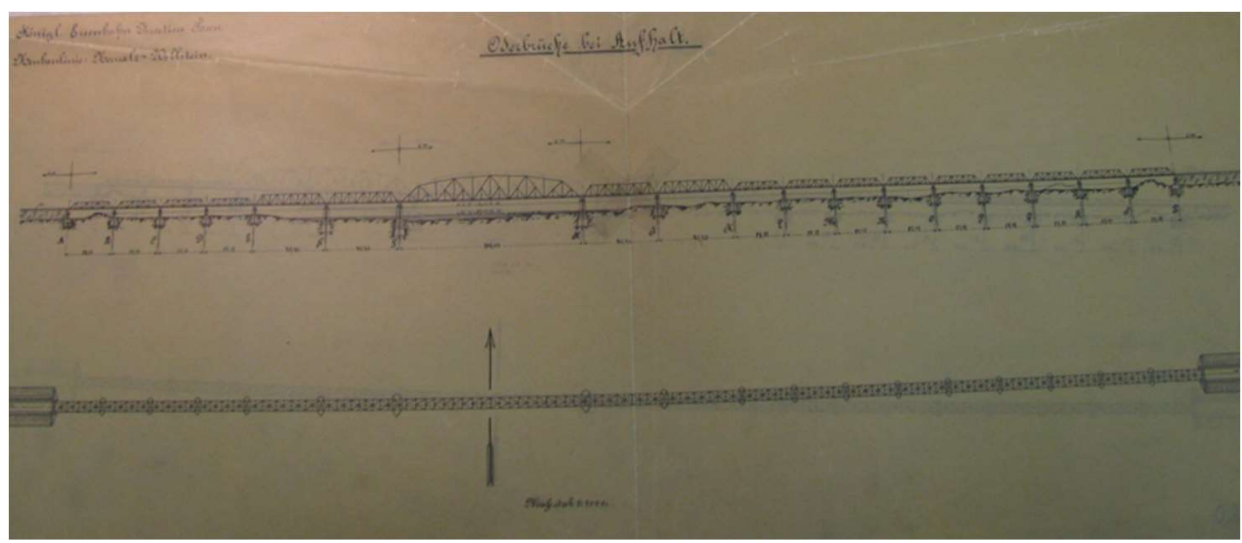

Fig. 4. Project of the bridge - a side and top view (Beuchelt \& Co., 1903, State Archives in Zielona Góra)

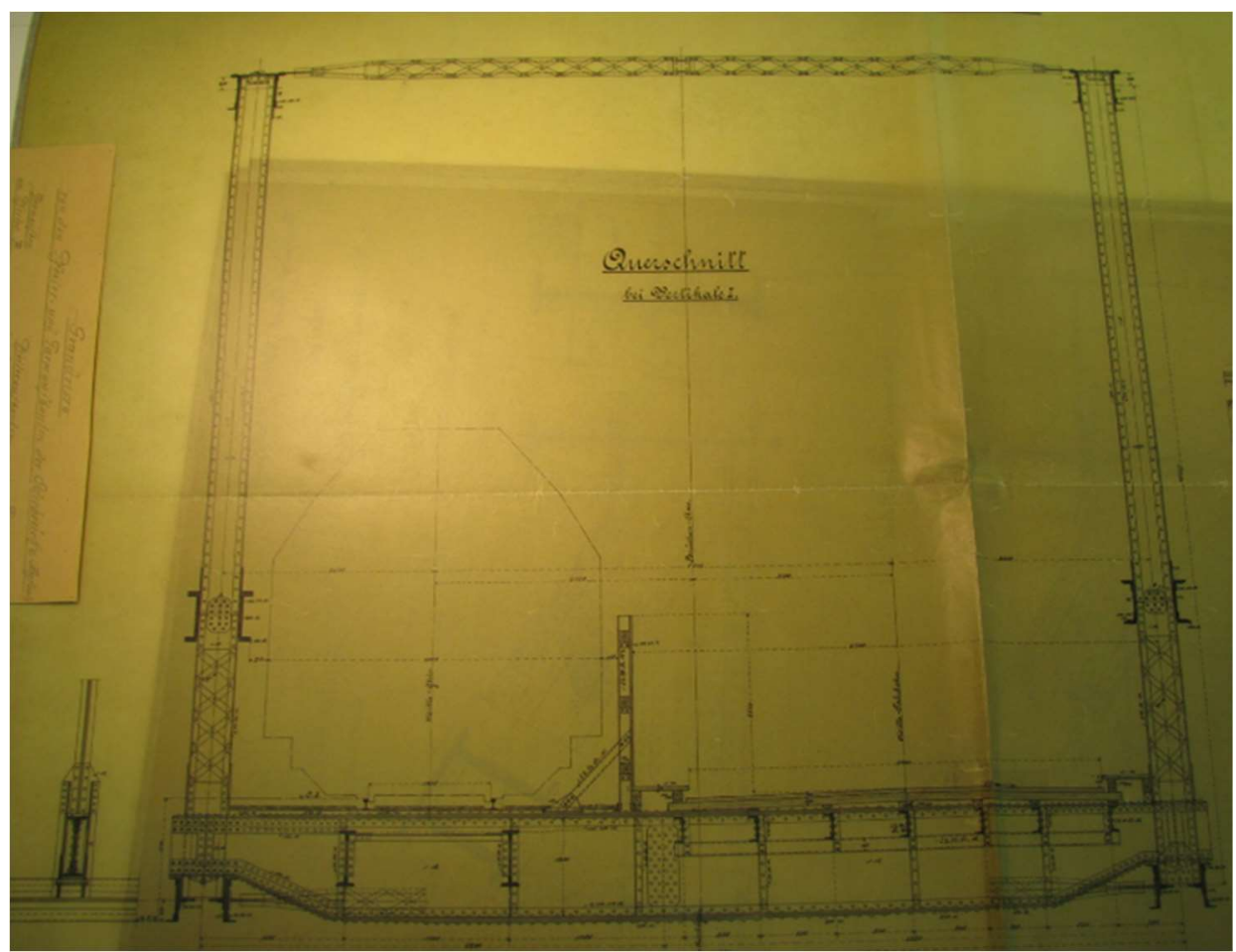

Fig. 5. Project of the bridge - a cross-section (Beuchelt \& Co., 1903, State Archives in Zielona Góra) 
Finally, it was decided to have a single span of $100.00 \mathrm{~m}$, four spans of $40.40 \mathrm{~m}$ in the centre section and fourteen spans of $27.80 \mathrm{~m}$. Each span was made as a freely supported beam. The structure of the river span was an arched truss, while in the other sections it was a flat truss. All the components of the spans were joined with rivets, which was typical of that period. The supports were constructed as a concrete structure covered with stone blocks. They were streamlined, matching the direction of the river current. The bridge spans were supported on strong steel bearings. The present layout of the bridge is significantly different, probably due to the fact that the object was blown up on 3 February 1945 during the evacuation of German troops and then rebuilt in 1955. Firstly, the total length of the crossing was reduced by $8 \mathrm{~m}$, the number of spans was also reduced to fourteen. During the reconstruction the structure of the river span was rebuilt as flat like the other spans instead of the original arched structure.

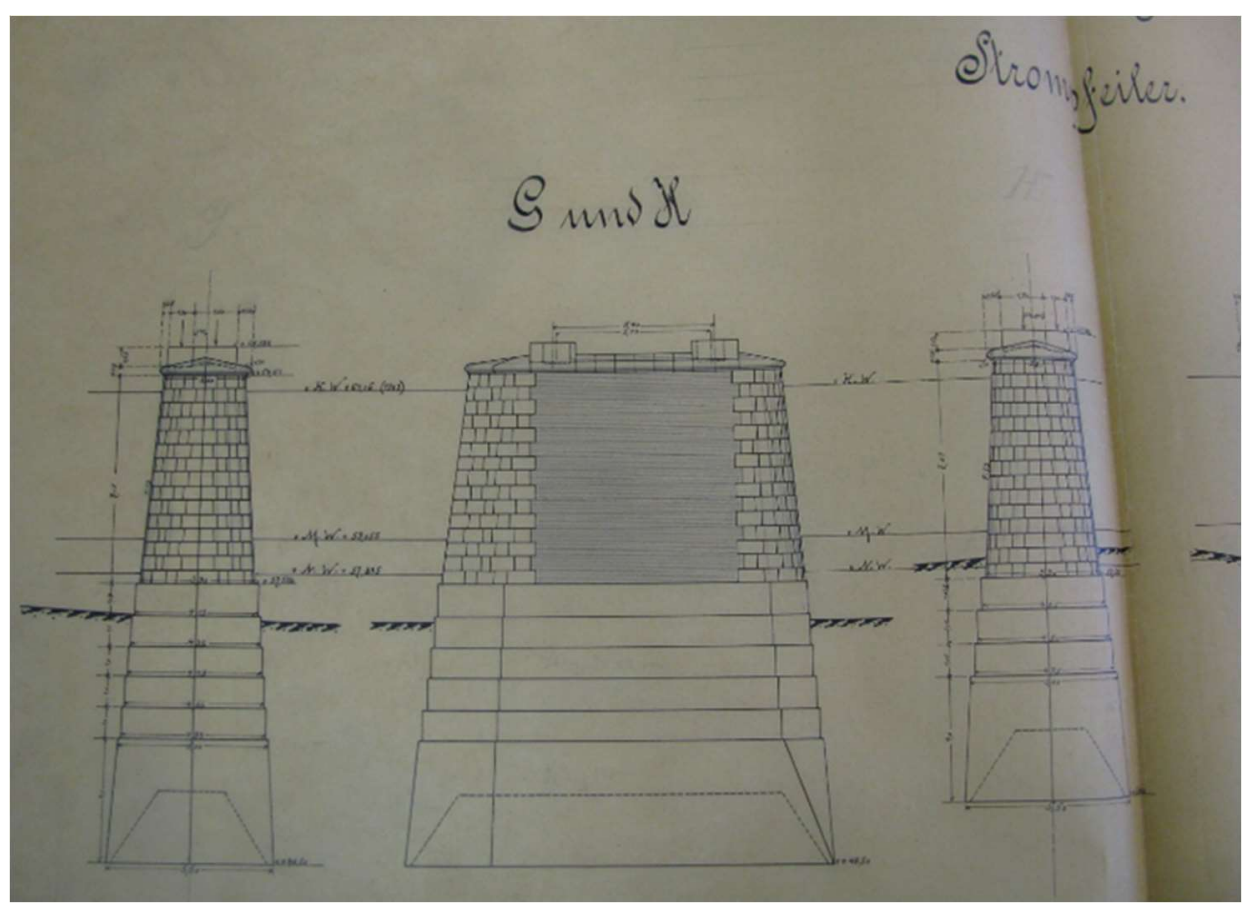

Fig. 6. Project of the bridge - the river span supports (Beuchelt \& Co., 1903, State Archives in Zielona Góra)

The support structure was covered with fired ceramic bricks instead of stone blocks. Additional changes can be found in the cross section. The object was originally designed as a railway and road bridge with one railway track and a traffic and pedestrian lane. At present it is only a single-track railway bridge with 


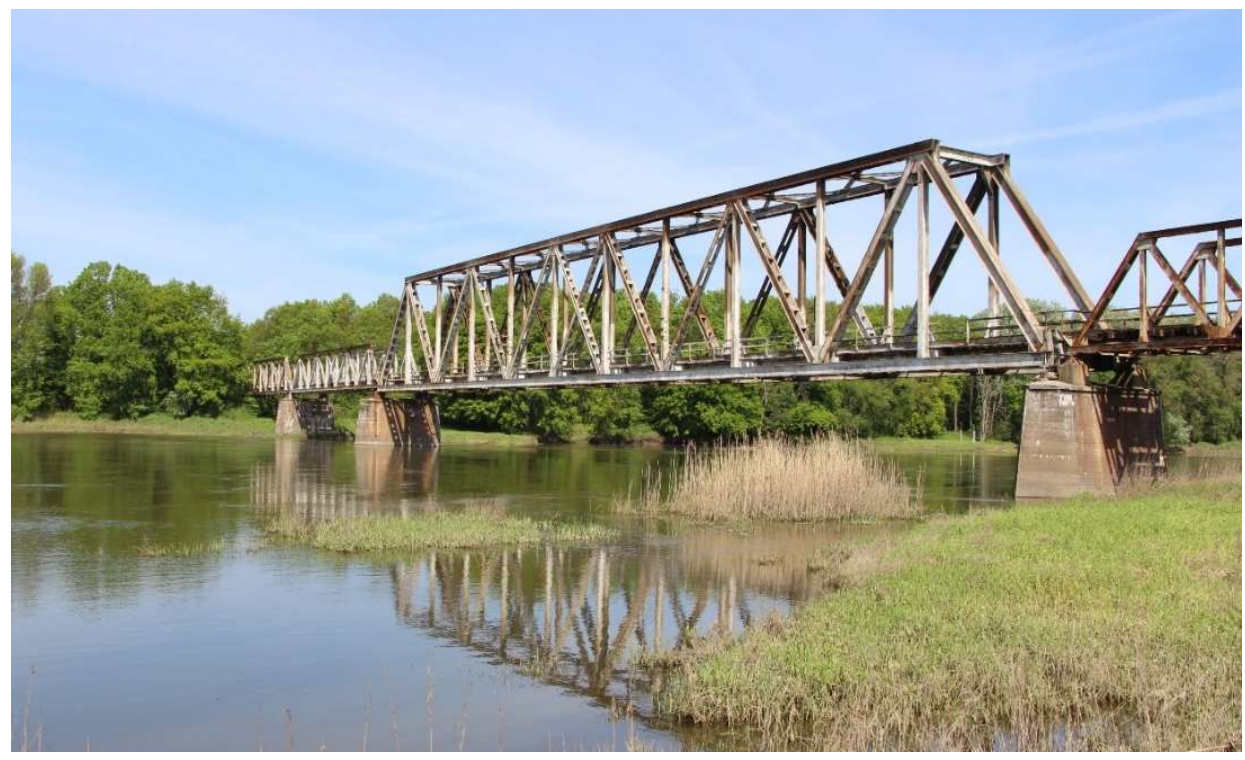

Fig. 7. Parallel lattice of the river span, a view from the western side (photo by the Author, 2017)

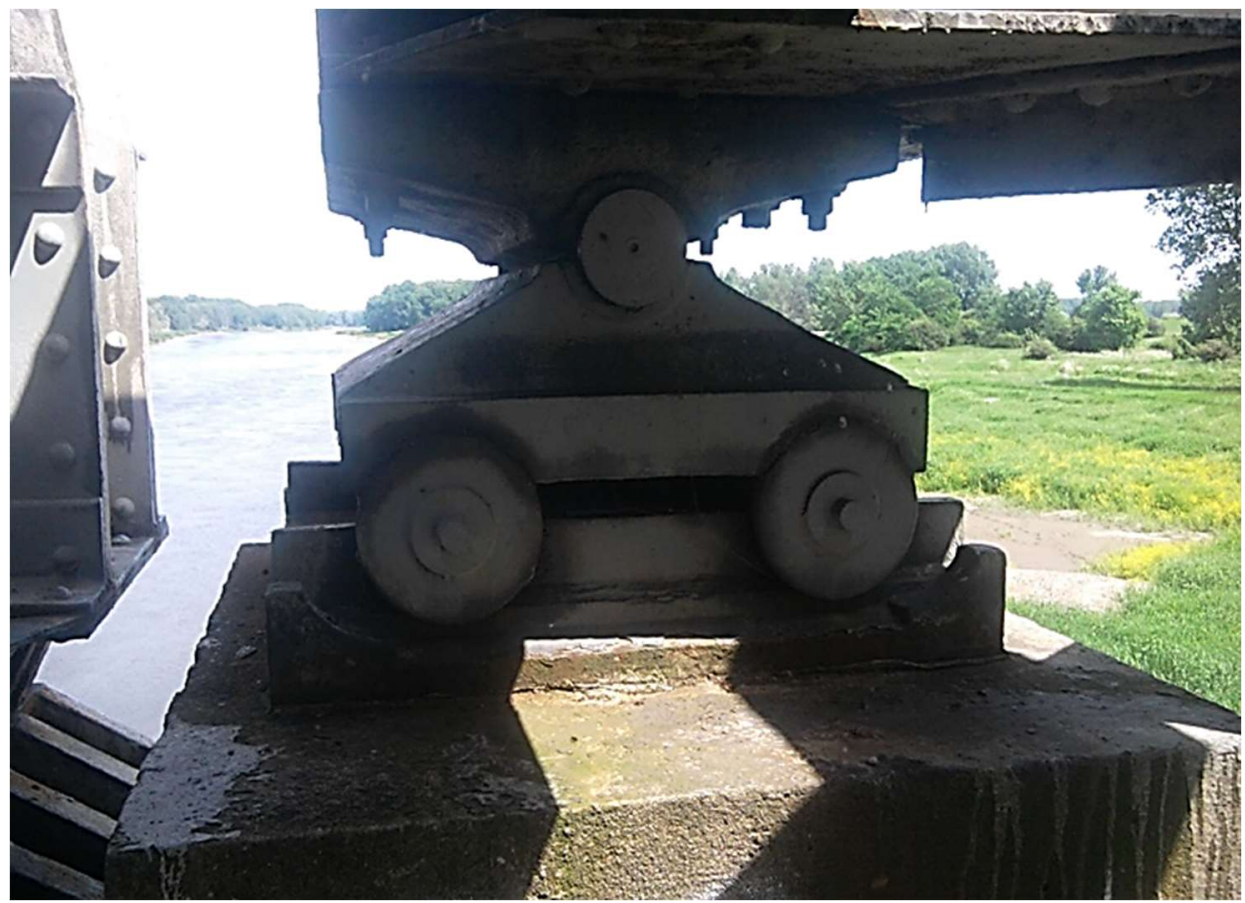

Fig. 8. Steel sliding bearing (photo by the Author, 2012) 
a maintenance footpath. However, it is not possible to say firmly whether all the changes to the original design were made during the post-war reconstruction of the bridge or during its construction in 1905 or during subsequent renovations. There is a hint in a drawing from 1908, which shows a crane assembly with a capacity of $500 \mathrm{~kg}$ on one of the spans and a cross section of the bridge with only one track without a traffic lane.

\section{FORTIFICATIONS - BLOCKHAUS}

Apart from the impressive size, another element distinguishing the bridge in Stany from other railway bridges in the Lubusz Voivodship are so-called blockhouses (German Blockhaus). This name refers to small buildings located near the bridgeheads, more precisely at the intersection of the levee with the railway embankment. They were defensive structures, built in neo-Gothic style. Unfortunately only one of them on the western side has been preserved to this day. The bridge was fortified in this manner, typical of the Prussian army, due to the considerable distance from the nearest military garrisons in Sulechów and Głogów. Buildings of this type played an important defensive role in case of an enemy attack to take control of the railway line, which was an important strategic object. The blockhouses were located on the levee because of significant annual fluctuations in the water level in the Oder River, but at the same time they gave the soldiers an excellent view of the wide, lowland area around the bridgeheads. The buildings themselves were erected in the form of two-floor towers measuring $4.28 \mathrm{~m}$ to $6.40 \mathrm{~m}$, built of ceramic bricks, which had been brought specially for this purpose from the Ruda Śląska. The first floor was used as a social, storage room, the second one was used for observation and defence. The two floors were connected with metal ladders. The troops could also move between the towers using footpaths on the track level or in battle conditions through tunnels. The soldiers stationed in the blockhouses had access to their own drinking water from a well as well as to electricity and telegraph lines, so if enemy troops were noticed, they could quickly inform headquarters. It is interesting that neo-gothic architectural ornaments such as crenellations, which had a merely decorative function, were used in military buildings. Very similar blockhouse designs were used during the construction of Ernest Malinowski Bridge in Torun, located on the Poznań-Olsztyn railway line (1873). 
THE HISTORIC STEEL BRIDGE IN STANY. HERITAGE PRESERVATION. CHANGING THE FUNCTION

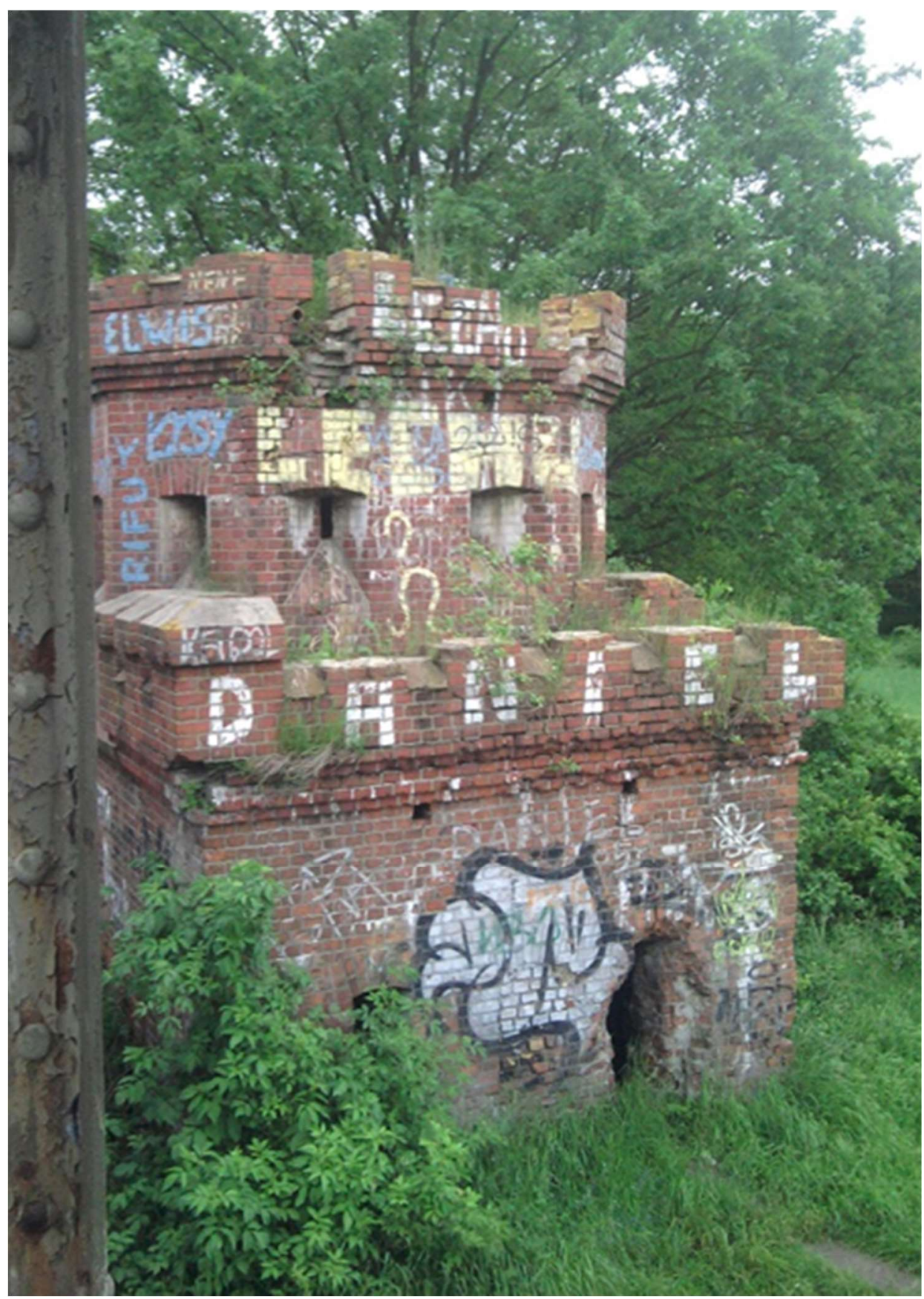

Fig. 9. Blockhouse view from the western side (Photo by the Author, 2012) 


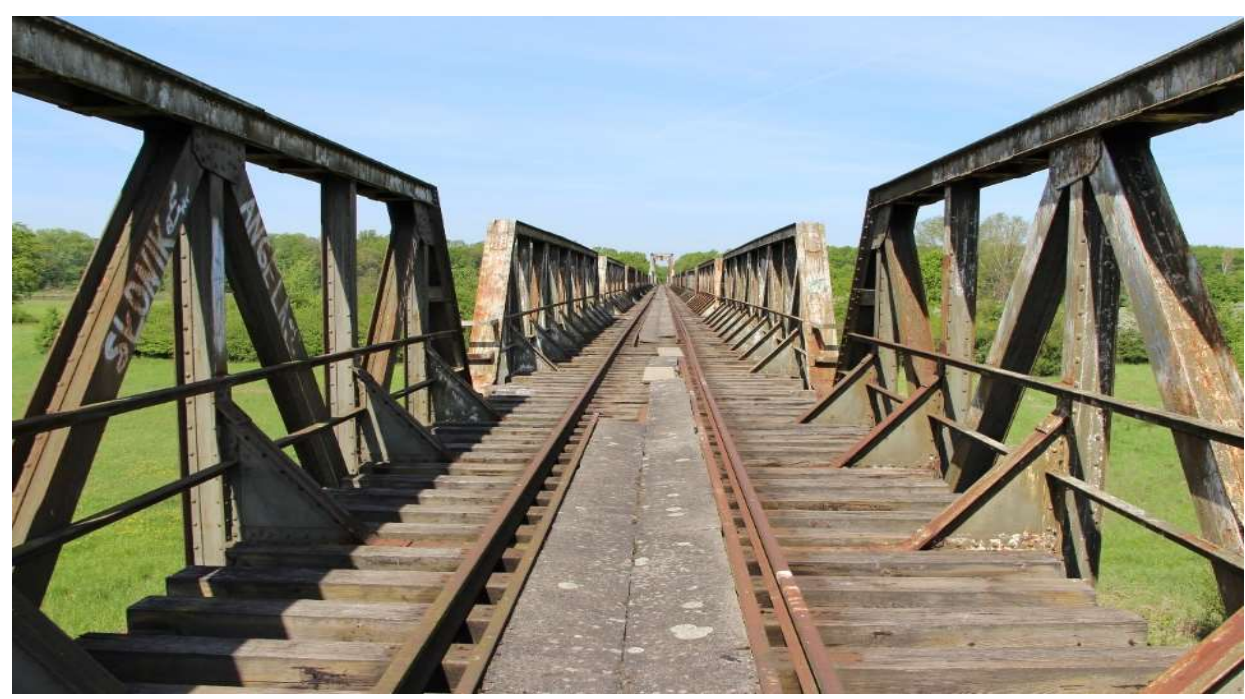

Fig. 10. View of the bridge from the rail level (Photo by the Author, 2017)

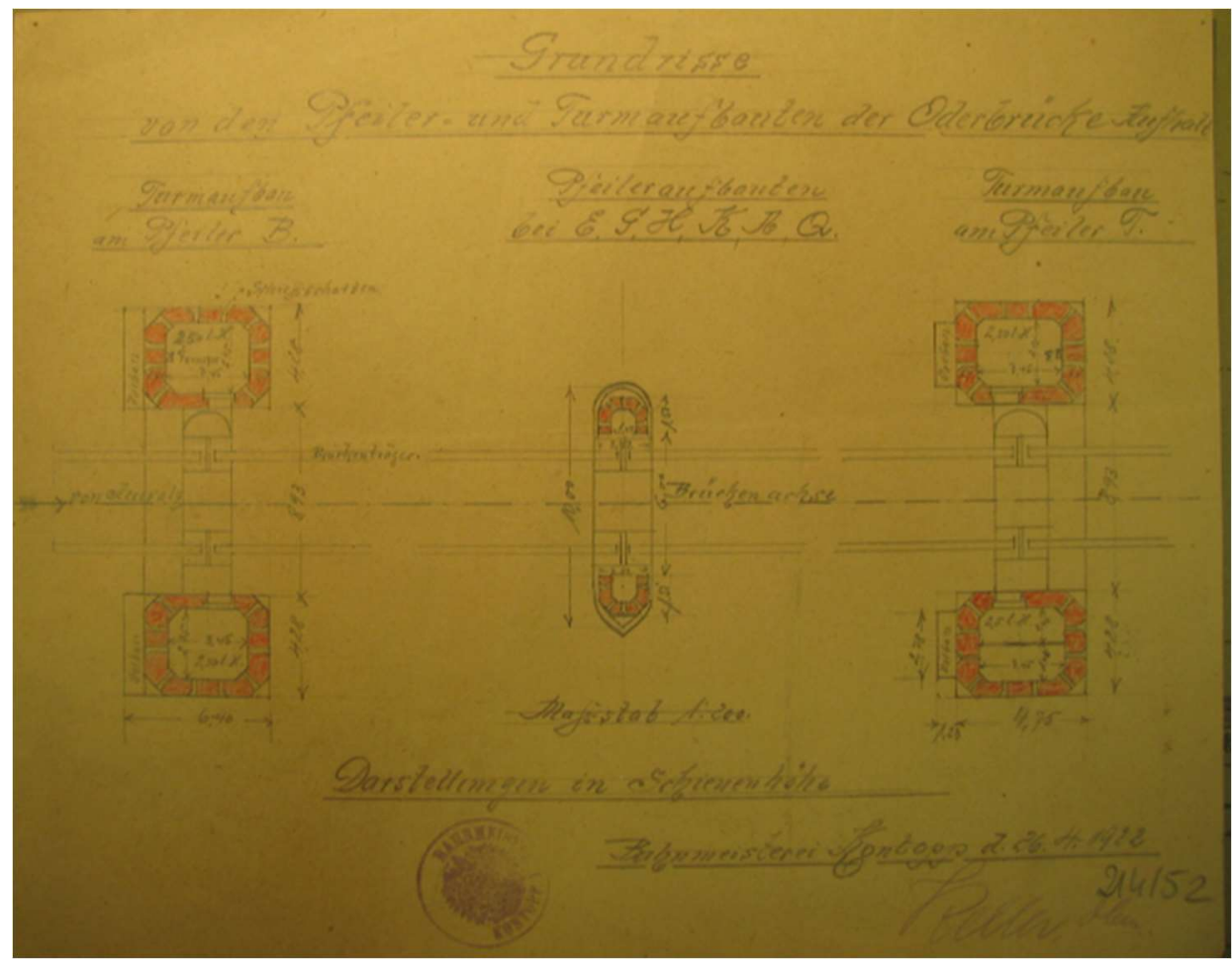

Fig. 11. Schematic of the layout of the supports and the blockhouses (Beuchelt \& Co., 1922, State Archives in Zielona Góra) 


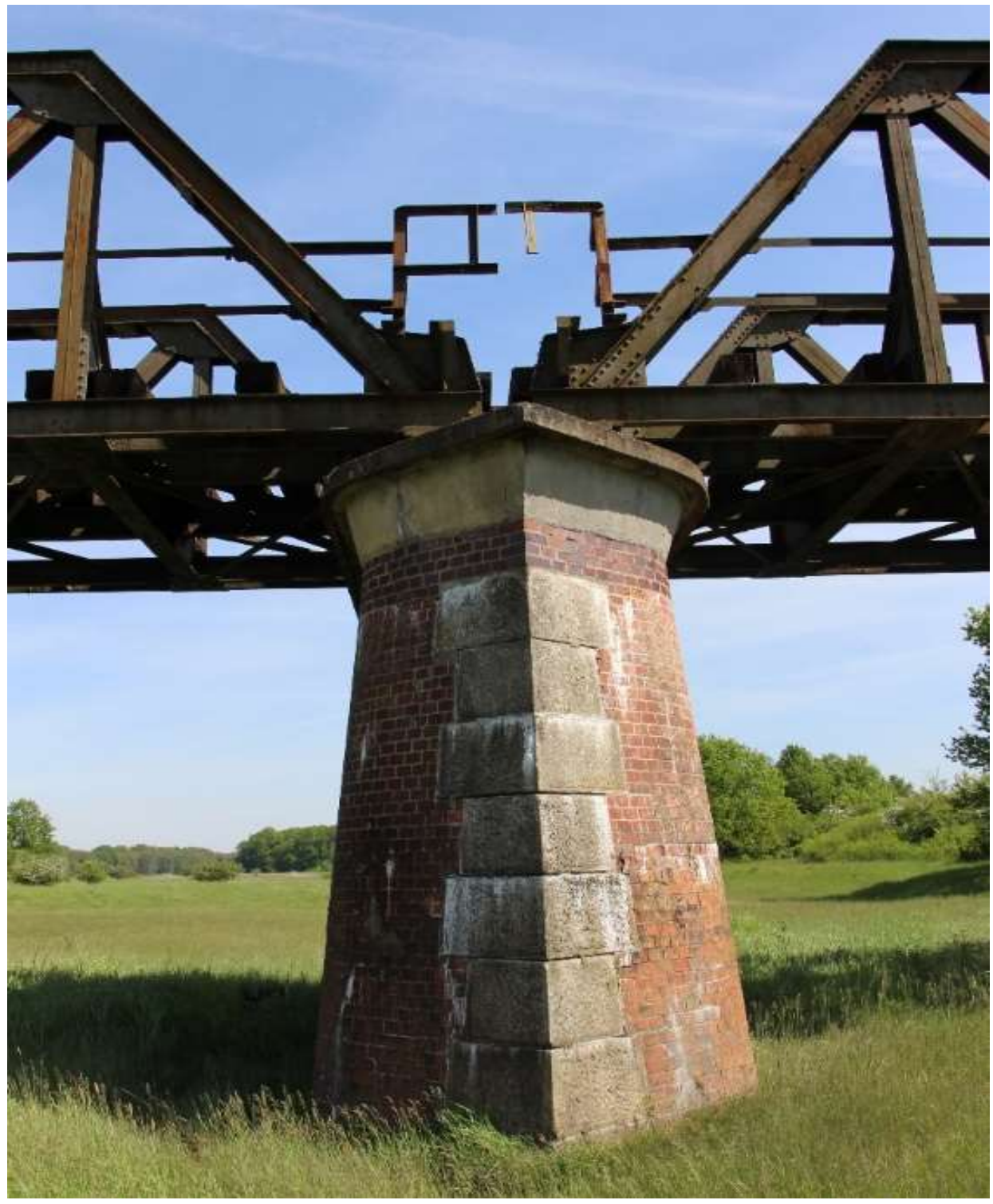

Fig. 12. View of the support (Photo by the Author, 2017)

\section{CONCLUSION}

During the reconstruction of the bridge, which had been blown up in February 1945, the eastern complex of blockhouses was dismantled. After the 
reconstruction the bridge was re-commissioned for 42 years and finally in 1997 the railway line from Wolsztyn to Nowa Sól was closed due to the damage caused by the flood of the century on the Oder River. Since then the object has not been used. Unfortunately, the lack of maintenance and vandalism cause the bridge to gradually fall into ruin. There is no doubt that further lack of activities aimed at protecting and preserving it will make it necessary to dismantled it one day, which will be a great loss because of its high value as a monument in the Lubusz Voivodship. It is one of the largest and most impressive bridges with a steel structure in the region and in Poland, in addition it is a fortified bridge with a wellpreserved blockhouse complex, which makes the building a unique example of historical engineering. For the inhabitants of Zielona Góra it should also be a valuable monument associated with Georg Beuchelt's factory producing steel structures, which used to be the pride of the town. This plant was a European leader both in the construction and railway industry. Objects made in the Zielona Góra plant, now known as ZASTAL, are still present in many European, African and Asian countries, and they are excellent examples of the history of technology. Unfortunately, the unique bridge in Stany has been out of operation since the 1990s and is gradually falling into ruin. The impressive size of the bridge (the second longest river span in railway bridges in Poland) and the partially preserved fortification system deserve to be given more attention and restored to a state of splendour. Fortunately, there are far-reaching plans to build a 50 kilometre bicycle lane in the place of the former Nowa Sól-Wolsztyn railway line with funds from the European Union. During this project the bridge would be renovated and adapted for cyclists [7]. These actions are needed or even necessary, and they are within the remit of local authorities. Monuments of technology of such great value should be carefully examined, preserved and maintained in good technical condition. It is necessary to properly use the bridge in order to protect it.

\section{REFERENCES}

1. Original design-technical documents by Beuchelt \& Co, 1903. State Archives in Zielona Góra.

2. Beuchelt \& Co., Design documents of the bridge in Stany, 1903. State Archives in Zielona Góra.

3. Czyżniewski T., Georg Beuchelt (1852-1913), Zielona Góra 2011.

4. Foerster M., Der Bauingenieur. Zum 50 Jährigen Bestehen der Eisenkonstruktionswerkstaten und Brückenbauanstalt Beuchelt \& Co. in Grünberg, Schlesien, Berlin 1926.

5. Hof A., Das deutsche Eisenbahnwesen der Gegenwart, Berlin 1923. 
6. Museum of the Lubusz Region, Exhibition of documents and photographs Steel empire. The history of Beuchelt \& Co., Zielona Góra 2015.

7. Szczecińska A., Kula M., Transgraniczna koncepcja zagospodarowania turystycznego Doliny Środkowej Odry, Nowa Sól 2015.

8. Woźny A., Od Grünberga do Zielonej Góry, Zielona Góra 2007.

\section{ZABYTKOWY MOST STALOWY W STANACH. OCHRONA DZIEDZICTWA. ZMIANA FUNKCJI.}

\section{Streszczenie}

Stany to mała wieś położona w pobliżu miasta Nowa Sól w województwie lubuskim. W odległości kilkuset metrów od budynków znajduje się jedna z najciekawszych atrakcji województwa lubuskiego - pochodzący z początku XX wieku most kolejowy. Jest to nitowana, stalowa konstrukcja kratownicowa $\mathrm{z}$ pasami równoległymi. Projekt został wykonany przez firmę Fabrik und für Brückenbau Eisenkonstruktionen BEUCHELT \& Co. Grünberg in Schlesien (dzisiaj ZASTAL). Most składa się z czternastu przęseł o łącznej długości $642 \mathrm{~m}$. Najdłuższe przęsło nurtowe ma rozpiętość 100,01 m. Długość przęsła nurtowego kwalifikuje most w Stanach w krajowej czołówce i daje mu drugie miejsce w Polsce i pierwsze w województwie lubuskim. Most był użytkowany nieprzerwanie do 1994 r. Od tego momentu obiekt jest nieczynny, a jego stan techniczny z roku na rok się pogarsza. Most jest wyjątkowy zarówno w skali kraju jak i Europy, co zachęca do dokładnego opisania i zbadania jego konstrukcji. Planowany jest jego remont i adaptacja do nowych celów. Most nie będzie wykorzystywany zgodnie $\mathrm{z}$ poprzednią funkcją, ale zostanie dostosowany do potrzeb planowanej w miejsce dawnej linii kolejowej ścieżki rowerowej.

Słowa kluczowe: Beuchelt, Stany, most stalowy, kratownica stalowa, Odra

Editor received the manuscript: 10.06.2018 